\title{
Exploring the Relationship between Ethical Sales Behavior, Relationship Quality, and Customer Loyalty
}

\author{
Laith Alrubaiee \\ Associate Professor of Marketing, Department of E-Business, Faculty of Business \\ Middle East University - MEU, PO box 383, Amman 11831, Jordan \\ Tel: 962-79-699-9576_E-mail: Lalrubaiee@meu.edu.jo or Laith_alrubaiee@Yahoo.com
}

Received: August 30, $2011 \quad$ Accepted: October 21, $2011 \quad$ Published: February 1, 2012

doi:10.5539/ijms.v4n1p7 URL: http://dx.doi.org/10.5539/ijms.v4n1p7

\begin{abstract}
In today's heightened ethical awareness and increased competitive pressure, the implications of ethical behavior for financial institutions have become a vital determinant of customer loyalty. The purpose of this study is to develop a conceptual framework to investigate the relationship between ethical sales behavior, relationship quality, and customer loyalty. The proposed model is tested on data collected from 217 bank customers. Structural equation modeling technique was employed using AMOS 7.0 to verify the reliability and validity of the multi-item scales and to test the hypothesized relationships. Result indicates that ethical behavior did increase customer loyalty to the bank; yet this effect was not direct, but mediated by customer trust and customer commitment to the bank. Findings also indicate that, customer trust in the bank has positive effects on customer commitment to the bank. The result of this study positions customer trust and customer commitment as the primary mechanism through which the beneficial effects of ethical sales behavior are realized. However, the study show that perceived ethical behavior has a major impact on the development and maintenance of the customer-bank relationship. Bank manager, which value the critical importance of long term relationships with their customers, should achieve an environment where the potential for unethical behavior is at a minimum.
\end{abstract}

Keywords: Ethical sales behavior, Relationship quality, Customer loyalty, Customer trust, Customer commitment, Bank customer, Structural equation modeling

\section{Introduction}

In today's heightened ethical awareness and highly competitive environment in the financial services industry, the ability of a financial institution to compete on price has become increasingly difficult. Therefore, most service marketers recognize today the importance of initiating and maintaining enduring relationships with customers (Liu et al. 2008; Sin et al., 2002; Narayandas \& Rangan, 2004; Lam \& Burton, 2006; Lemon et al. 2002; Wang et al., 2008; Wilson, 1995). This is particularly true in services contexts such as financial services, characterized by continuous exchange activity and considerable purchase uncertainty. For a bank to maximize its long-term performance in such aspects as customer retention and loyalty, it must build, maintain and enhance long-term and mutually beneficial relationships with its target customers (Alrubaiee \& Alnazer, 2010; Reynolds \& Beatty, 1999; Levesque \& McDougall, 1996). However, in this era of strategic customer relationship environment, business ethics has become a significant boardroom topic (Nill \& Schibrowsky, 2007; Dunfee et al. 1999). The implications for financial institutions are that it is of increasing importance that new, non-price factor, such as ethical sales behavior of salespeople is used as a means of differentiation, to achieve higher revenue growth and improved market share (Roman, 2003; Ferrell et al., 2007). The focus on building successful customer relationships puts salespeople in a critical strategic position relative to the customer (Hansen and Riggle, 2009; Matthew et al., 2007; Schwepker, \& David, 2005; Schwepker \& David, 2007b; Swan et al.,1999). Furthermore, ethical sales behavior can play a critical role in the formation and maintenance of long-term relationships with customers (Roma'n \& Ruiz, 2005; Chen \& Mau, 2009; Amyx et al., 2008; Schwepker \& David, 2004; Lagace et al., 1991). However, in the financial services context, the salesperson's ability to affect customer's loyalty and dependency on the financial institution may be determined largely by the behaviors they implement when interacting with the customer (Reddy and Czepiel 1999; Strout, 2002; Goff et al., 1997; Pressey $\&$ Mathews, 2000). Furthermore, the pressure toward unethical behavior may be even stronger among sales representatives. Meeting quotas and competing successfully in relatively weak economic times may have caused 
an increase in unethical behavior among sales representatives toward customers (Mantel, 2005; Schwepker et al., 2007a; Dubinsky \& Levy, 1985). However, financial services are highly abstract services characterized by credence attributes and consequently difficult for consumers to fully understand. Furthermore financial institutions are vulnerable to many legal and ethical abuses and very expensive forms of corruption. Hence, the customer must rely on the salespeople for correct information and proper guidance. Because ethics is a central issue in financial services, and to avoid deceptive sales practices, ethical sales behavior can play a critical role in the formation and maintenance of long-term relationships with customers (Lamb 1999; Dunfee and Gunther 1999). Therefore, retaining customers and maintaining customer loyalty demands that banks must listen to their customers and understand their needs (Dibb and Meadows 2001; Adamson \& Handford, 2003; lasser et al., 2000; Selnes, 1998; Dick \& Basu, 1994; Prim, 2004). Researches indicate that salespeople who act in an ethical manner are more effective at building strong customer relationships and their customers are more satisfied with them, more trusted and/or committed to them (Hansen and Riggle, 2009; Walter et al., 1999; Goff et al., 1997). If good ethics is good business, the consequences of such initiatives should be enhanced business results. Taking the "high road" with more ethical strategies should translate into greater market share and return on investment, which leads to long-term sustainability of organizations (Weeks et al., 2006). However, findings of Vegholm and Silver (2008) study imply that banks must encourage behaviors that will increase customers' confidence in the bank organization. These suggestions are in line with the thoughts of Llewellyn (2005), who argues that it is important for financial institutions to set guidelines for individual bankers on how to act fairly, and to develop appropriate training and reward mechanisms. Although many related topic articles were published, Liljander and Mattson (2002) posited that further studies are required regarding the effect of employee ethical behavior and particularly salesperson behavior on customer loyalty. Moreover, despite a general recognition that ethical sales behavior plays a critical role in the relationship development process, there have been limited empirical demonstrations of this reality (Hansen and. Riggle, 2009). Accordingly, the purpose of this study is to better understand the relationships among the ethical sales behavior, relationship quality and customer loyalty to bank. More specifically, study aims to empirically investigate the mediating effect of customers' trust and customer commitment in ethical sales behavior - customer loyalty relationship. Such understanding could contribute to improving the ethical behavior of the salespeople and consequently enhance the opportunity to build long-term profitable customer relationships in the context of Jordanian banking industry. Furthermore, this study is of great value to the banking sector since it shows bank managers how to gain customers' trust, commitment and loyalty to the bank through the ethical behavior of their frontline employees.

\section{Literature review}

\subsection{Ethical sales behavior}

According to Román and Ruiz (2005), ethical behavior in the sales relationship context denotes behaviors on the part of the salesperson that promote the welfare of the customer. Nevertheless, Román and Munuera (2005) defined ethical sales behavior as fair and honest actions that enable the salesperson to foster long-term relationships with customers based on customer satisfaction and trust. Salespersons typically have personal interactions with the customer and their actions are more readily visible, and unethical behavior can have a profound effect on the public opinion of the company (Mantel, 2005). Definitions of ethical behavior versus unethical behavior are based upon the degree to which a proposed act is perceived as right versus wrong, good versus evil, fair versus unfair, or just versus unjust (Roman, 2003). Ethical sales behavior is a highly elusive construct and is often situation-specific (Lagace et al., 1991). However, unethical sales behavior as perceived by the customer is defined as a short-run salesperson's conduct that enables him/her to gain at the expense of the customer. Examples of such activities include: lying or exaggerating about the benefits of a product/service, availability, the competition, selling products/services that people do not need, giving answers when the answer is not really known, and implementing manipulative influence tactics or high-pressure selling techniques (Cooper and Frank 2002; Futrell 2002). A salesperson's unethical behavior may negatively impact customer satisfaction and retention. Dubinsky et al. (1992) contends that unethical salesperson behaviors may result in customer dissatisfaction, poor word-of-mouth, lost customers, reduced sales and profits (Burnett et al., 2008). Therefore, the study focuses on salespeople's ethical behavior as perceived by customer who takes place during the interaction between them and the bank's salespeople.

\subsection{Relationship quality}

Relationship quality has been originally termed as a bundle of intangible value that augments products or services and result in an expected interchange between buyers and sellers (Levitt, 1986). Relationship marketing quality can be considered as an overall assessment of the strength of a relationship (De Wulf et al, 2001). Relationship marketing theory suggests that successful relationship marketing results from certain aspects of 
cooperative relationships that characterize successful relational exchanges (Hunt et al, 2005). Relationship quality is a higher order construct depicting the value customers attach to their relationship with the service provider (Dorsch et al., 1998). According to Hennig-Thurau and Klee (1997), relationship quality can be seen as the degree of appropriateness of a relationship to fulfill the needs of the customer associated with that relationship. However, Berry (1983) perceived relationship marketing as a tool from which customer loyalty can be secured and, as a result, the attainment of higher competitiveness and enhanced customer satisfaction can be achieved. Relationship marketing represents a strategic response by firms to gain competitive advantage (Takala and Uusitalo, 1996). This response is based on the theory that appreciation of the interdependence of market players, and mutual effort based on trust and commitment, would allow firms to remain competitive (Veloutsou et al., 2002). Research suggests that the benefits of relationship marketing are many, including improvements in competitive advantages in the marketplace superior financial performance and increased levels of customer satisfaction. According to Arnett and Badrinarayanan (2005) studies suggest numerous factors that influence relationship marketing success i.e. relationship quality, even though three factors consistently identified as important are trust, commitment and communication. Nevertheless, most research has conceptualized the effects of relationship marketing on outcomes as fully mediated by one or more of the relational constructs of trust, commitment, satisfaction, communication and/or relationship quality (Alrubaiee \& Alnazer,2010). It has been conceptualized as a higher-order construct consisting of several distinct, though related dimensions, with critical importance of relationship satisfaction, trust and relationship commitment (Bonnin et al., 2005). Researchers have suggested that these Components are merely indicators of the global mediator relationship quality, which is an overall assessment of the strength of a relationship and is conceptualized as a multidimensional construct that captures the many different facets of an exchange relationship. Its structure and underlying dimensions vary across empirical studies, but central to the conceptualization is the belief that no single dimension or relational construct can fully define the overall depth or climate of an exchange relationship (Johnson et al., 1999; Garbarino \& Johnson, 1999; De Wulf et al, 2001; Alrubaiee \& Alnazer, 2010). For example, Morgan and Hunt (1994) propose that trust and commitment are both key to predicting exchange performance, whereas some others suggest that either trust or commitment alone is the critical relational construct (Palmatier et al., 2006). Another school of thought suggests that the global construct of relationship quality, as reflected by a combination of commitment, trust, and relationship satisfaction, offers the best assessment of relationship strength and provides the most insight into exchange performance (De Wulf et al, 2001). However, the study conceptualizes a relationship quality as a bank's ability to identify, develop, and manage cooperative relationships with key customers characterized by trust and commitment. Therefore, the development of a relationship quality is important to develop long-term relationships with key customers.

\subsection{Trust}

One of the goals in the regulation and supervision of financial markets is to enhance trust in financial institutions and in the financial system (Masciandro et al., 2007; Grunbichler and Darlap, 2003; Hasan and Severiens, 2001). The objective of financial institutions is, therefore, to convey trust to their customers so as to comply with regulatory standards (Ferna'ndez-Laviada, 2007; Vegholm and Silver, 2008). The majority of definitions for trust describe it as the belief by one firm that a partner will perform actions producing positive results for the former (Alrubaiee \& Alkaa'ida, 2011). As Sirdeshmukh et al., (2002) stated trust is the expectations held by the consumer that the service provider "can be relied on to deliver on its promises". Hall (2005) explains that those who trust have an expectation that the trusted person will behave with goodwill towards them and with competence in the domain in which he or she is trusted (or in caring for that with which he/she is entrusted). Customer trust in the relational sales context can be defined as a confident belief that the salesperson can be relied upon to behave in such a manner that the long-term interest of the customer will be served (Crosby et al., 1990). According to Morgan and Hunt (1994) describes trust as" when one party has confidence in an exchange partner's reliability and integrity," is a central component in all relational exchanges. Trust regarded as a key ingredient for the development of long-term business and has been recognized as a highly significant tool for enhancing company relationships (Berry, 1995). Speckman (1988) posited that trust is central relationship construct; it has been referred to as "the cornerstone of the strategic partnership". According to Cater and Zabkar (2008) trust is belief, feeling or expectation about an exchange partner which can be judged from the partner's expertise, reliability and intentions. Mishra et al. (2008) posited that there are four dimensions of trust (i.e., reliability, openness, competence, and concern). Studies in the financial services industry revealed that trust is one of the most significant attributes valued by customers (Roman, 2003). 


\subsection{Commitment}

In the relationship marketing literature the concept of commitment plays a central role, as it is a major characteristic of relationship marketing models (Alrubaiee \& Alnazer, 2010). Research suggests that relationship commitment is at the core of all successful working relationships and that it is an essential ingredient in successful long-term relationships (Anderson and Narus, 1990). Relationship Commitment refers to an implicit or explicit pledge of the continuity of a relationship between exchange partners. It has served as the dependent variable in several relationship marketing models including those describing buyer-seller relationships and channel behavior; it is a good indicator of long-term relationships (Morgan and Hunt, 1994) and is thought to represent the peak in relational bonding (Dwyer et al., 1987). Commitment has been operationalized in several ways, including desire to continue the relationship, willingness to make short-term sacrifices, confidence in the stability of the relationship, and investments in the relationship (Kim \& Frazier, 1997).

\subsection{Customer loyalty}

Customer loyalty is defined by Oliver (1999) as a deeply held commitment to re buy or re patronize a preferred product or service in the future despite there are situational influence and marketing efforts having the potential to cause switching behavior " (Yim et al. 2008). Fornell (1992) thinks that loyalty is the function of satisfaction, switching barriers and voice. Loyal customers may not be always satisfied, but satisfied customers are apt to be loyal (Fornell, 1992). Bitner (1990) describes loyalty as a process. At the end of the process, satisfaction has effects to perceived quality, which could cause loyalty and intention to certain behavior (Alrubaiee \& Alnazer, 2010). An expectation of continuity reflects the customer's intention to maintain the relationship in the future and captures the likelihood of continued purchases (Palmatier et al., 2006). Increased customer loyalty is one of the most common outcomes expected from relationship marketing efforts.

\subsection{Relationship among study variables}

Researches indicate that successful relationship marketing efforts, i.e. relationship quality, improve customer loyalty and firm performance through stronger relational bonds (e.g., De Wulf et al., 2001; Sirdeshmukh et al., 2002; Alrubaiee \& Alnazer, 2010). Trust and commitment are often jointly examined in relationship marketing research. Many researchers regard trust as an antecedent of both commitment and successful relationships (Cater \& Zabkar, 2008; Stanko et al, 2007). However, studies suggest that trust as one of the prominent behavioral determinants of commitment (Morgan and Hunt, 1994; Coote et al., 2003; Doney \& Cannon, 1997; Karande et al, 2008). Trust has a direct positive impact on commitment. Trust diminishes the perceived risk and vulnerability in a relationship and thus leads to a higher commitment to the relationship. Trusted parties can be relied upon to fulfill their expectations, which results in greater commitment (Ganesan, 1994). If a supplier is not perceived to be benevolent, honest or competent enough to show useful behavior regarding the relationship in question, the customer cannot rely on this supplier and thus will show no commitment towards the relationship (Morgan and Hunt, 1994). Cater\& Zabkar (2008), thus, suggests that in relationships where trust is high, it is more likely that clients will continue the relationship because they like the provider and enjoy working with him. Therefore, several studies have found empirical evidence about the positive influence of trust on commitment. Alrubaiee \& Alnazer (2010) study provides initial empirical evidence of the impact of relationship marketing on bank customer loyalty. Holden (1990) suggests that the salesperson's ethical sales behavior is positively related to customer trust. The results of Chen and Mau, (2009) studies show that ethical sales behavior plays a major role in affecting customer trust. Moreover, customer trust is an important mediating determinant between the salesperson's ethical sales behavior and customer loyalty. In addition, Sanzo et al. (2003) found that, trust and commitment directly affect loyalty to supplier. On the other side, Wray et al. (1994) had suggested, that ethical sales practices, as perceived by financial services customers, increased customer trust in the salesperson. Likewise, different exploratory studies have shown that customer trust in the salesperson can be earned by the honest actions of sales representatives (Beatty et al. 1996), as well as low-pressure selling techniques (Strutton et al. 1996; Kennedy et al. 2001).Consistent with previous studies, Roman (2003) had investigated the direct consequences of ethical sales behavior. The study indicates that, this behavior had a positive impact on customer satisfaction with the core service, trust and loyalty to the company. Furthermore, Hansen and Riggle (2009) indicated that the relationship between ethical sales behavior and buyer commitment to the salesperson is completely mediated by buyer trust in the salesperson. Their finding revealed that the effect of ethical sales behavior on buyer commitment to the salesperson flow only through buyer trust in the salesperson. 


\section{Conceptual framework and hypotheses development}

\subsection{Conceptual framework}

It is now possible to develop an overall model summarizing the hypotheses and reflects a causal ordering derived from the literature reviewed above. The proposed structural model guiding this research is depicted in Figure 1. It builds on core linkages between study variables: ethical sales behavior, customer trust, customer commitment and customer loyalty. As can be seen in the figure, the relationship quality as mediator consists of tow constructs: customer trust and customer commitment. The research hypotheses are represented in the Figure. Ethical sales behavior is believed to have a positive relationship with customer trust, customer commitment and customer loyalty ( $\mathrm{H} 1, \mathrm{H} 2$ and $\mathrm{H} 6)$. It is suggested also that the relationship quality variables: trust and commitment, lead to customer loyalty to the bank ( $\mathrm{H} 4$ and $\mathrm{H} 5$ ). Customer trust is posited to have a positive influence on customer commitment (H3). Finally, as for indirect effects, customer trust and customer commitment are proposed as the key mediators that connect or bridge ethical sales behavior with customer loyalty (H7).

Insert Figure 1 here

\subsection{Research hypotheses}

The hypothesized relationships of the proposed structural model guiding this research are illustrated in Figure 1. Therefore, to examine these relationships the following hypotheses are formulated:

H1: Ethical sales behavior has a positive effect on customer trust in the bank.

H2: Ethical sales behavior has a positive effect on customer commitment to the bank.

H3: Customer trust in the Bank has a positive effect on customer commitment to the Bank.

H4: Customer trust in the Bank has positive effect on customer loyalty to the bank.

H5: Customer commitment to the Bank has a positive effect on customer loyalty to the bank.

H6: Ethical sales behavior has a positive direct effect on customer loyalty to the bank.

H7: Relationship quality (i.e. Customer trust and Customer commitment) mediates the effect of ethical sales behavior on customer loyalty to the bank.

\section{Research methodology}

This study is exploratory, quantitative in nature, aiming to develop a better understanding of the relationships among the ethical sales behavior, relationship quality and customer loyalty to the bank. More specifically, the study intends to empirically investigate the direct and indirect effect of ethical sales behavior as perceived by customer on his loyalty to the bank through customer trust and customer commitment as mediators.

\subsection{Selection of sample and respondents demographics}

The proposed research model is tested in the context of bank industry because financial services are highly abstract services characterized by credence attributes and consequently difficult for consumers to fully understand (Howe et al., 1994). Therefore, the customer must rely on the bank salesperson for correct information and proper guidance (Roma'n \& Munuera, 2005). Consequently, bank industry can adequately reflect the actual characteristics of ethical sales behavior relationships. Accordingly, the study is empirical based on the primary data collected from a sample of bank customers in Amman - Jordan. The study was carried out in 2010 on a convenience sample from four main Jordanian commercial banks: Arab Bank, Jordan-Kuwait Bank, Housing Bank for Trade and Finance and Ahli National Bank. Questionnaires were administered to a total of 320 bank customers within the area of Amman. A total of 226 respondents returned surveys, of which nine questionnaires were rejected due to the lack of some information. Thus, 217 valid questionnaires were finally obtained, giving response rate of 67.8 per cent, a rate that is regarded as good. Since the questionnaire was administered in Arabic, the questionnaire was drafted in English and translated into Arabic thereafter.

The participants in this study were predominantly males ( 54.4 percent), majority ( 53.4 percent) of the respondents were ages up to 40 years old. In terms of education, most of them (65.4 percent) were university graduates (possessed a bachelor degree) and the majority of the respondents work in the private sector (49.3 percent). Finally (55.1 percent) of the respondents were married.

\subsection{Data analysis}

The statistical package SPSS (version 19.0) was used for data analysis. A two-step detailed statistical analysis of data was involved. First, factor analysis was performed to extract the underlying factor of study variables. Second; a structural equation modeling was conducted using AMOS 7 to test the hypotheses in order to 
understand the direct and indirect effect of ethical sales behavior on - customer loyalty, customer trust and customer commitment.

\title{
4.3 Measures
}

All constructs in this study (i.e. ethical sales behavior, commitment, and trust and customer loyalty) were measured using multi-item Likert scale adapted from prior research previously validated in other contexts to ensure content validity. All items were measured using seven-point Likert-type scales. The respondents were asked to indicate their agreement or disagreement with the statements provided, with anchors of 1 to indicate 'strongly disagree' and 7 to indicate 'strongly agree'. The five items used to measure ethical sales behavior were adapted from those originally developed by Román (2003) to assess ethical sales behavior from the customer perspective in the Spanish financial sector. This scale was also adapted next by Román and Ruiz (2005); Chen and Mau (2009); Hansen \& Riggle, (2009). All items were negatively worded and subsequently reverse coded. The measure for trust were adapted from Morgan and Hunt (1994); Karande et al.(2008); Sanzo et al, 2003; Hansen and Riggle, (2009); Kennedy et al. (2001); Chen and Mau, (2009); Sirdeshmukh et al. (2002); Eisingerich and Bell,(2007). The eight items measure of customer trust designed to capture the major dimensions of trust: confidence, reliability, and integrity. These items were utilized as well, focusing specifically on those that capture respondents' perceptions as to the integrity and reliability of the bank/salesperson. The Seven items used to measure customer commitment was adapted from Morgan and Hunt (1994); Gruen et al.(2000); Wetzels et al., (1998); Sanzo et al, 2003; Karande et al.(2008) ; Hansen and Riggle, (2009); Kennedy et al. (2001); Chen and Mau, (2009). Customer loyalty was measured by a six-item scale developed by Sirdeshmukh et al. (2002); Chen and Mau, (2009); Hansen and Riggle (2009).

\subsection{Measure reliability}

Different procedures were carried out using SPSS 19 to examine the psychometric properties of the proposed measurements. As the first step in analysis of the scale, internal reliability for the adapted scale was compared to that reported in the developmental literature. Reliability analysis, understood as internal consistency, was carried out by calculating Cronbach's $\alpha$ coefficient .However, all the individual scales exceeded the recommended standards level of .70 proposed by Nunnally (1978) and Hair et al., (1998). As depicted in Table 1, the Cronbach alphas coefficients demonstrating the reliability of the scale used for measuring the constructs are at acceptable levels and fall between 0.865 for ethical sales behavior and 0.942 for customer loyalty, which suggests a high internal consistency among the items in each construct.

\section{Insert Table 1 here}

As can be seen in Table 1 these Cronbach alphas indicate that the scales used in the questionnaire satisfactorily measured the constructs, what means that the ability of the set of items employed to represent each of the latent constructs is satisfactory. However, unidimensionality of each construct must be checked. Therefore, items in each multi-item scale were factor analyzed separately using principal component factor analysis with Varimax rotation. The criteria for choosing variables are based on Kaiser's (1996) suggestions: an eigenvalue greater than 1 after Varimax rotation, absolute values of factor loadings greater than .50. As shown in Table 2, results indicate that in all case a single factor emerged, i.e. there is one factor derived from each variable. Ethical sales behavior (eigenvalue $=3.264$ ); customer loyalty (eigenvalue $=4.664$ ); customer trust (eigenvalue $=5.393$ ); and customer commitment (eigenvalue $=4.355$ ). Furthermore, all of the items in the research model had factor loadings greater than $0.70(0.73-0.91)$.

\section{Insert Table 2 here}

However, both tests of principal component analysis and Cronbach's alpha support unidimensionality and therefore were accepted as being reliable for the path analysis. In addition, a correlation matrix of the variables in the model was constituted and fall between 0.44 and 0.89 , as shown in Table 3, suggesting several highly significant correlations between the variables included in the conceptual model. Descriptive statistics and correlations among variables are presented in Table 3.

\section{Insert Table 3 here}

Thereafter, Following Anderson and Gerbing (1988), to assess construct validity of the multi-item scales confirmatory factor analysis (CFA) was conducted in order to determine if the extracted dimensions in step 1 offered a good fit to the data (Table 4).

\author{
Insert Table 4 here
}


According to Bagozzi and Yi, (1988) and Bearden et al., (1982), the CFA result provide overall fit indices: Chi-square was highly significant $(\mathrm{p}<0.001)$, the goodness of fit index (GFI) was 0.760 and adjusted goodness of fit index (AGFI) was 0.713; incremental fit index (IFI) $=0.882$; the normed-fit index (NFI) $=0.829$ and the root mean square residual $(\mathrm{RMR})=0.097$. All indices indicating that the measurement models provide good support for the factor structure determined through the exploratory factor analysis, which suggests the unidimensionality of the measures (Anderson \& Gerbing, 1988; Marcoulides and Schumacher's, 1996). According to Anderson and Gerbing (1988), the validity of the structural model is assessed using three key validity dimensions: nomological, discriminant and convergent. The nomological validity is the validity of the entire model and indicates whether the model fits the data; the discriminant validity refers to the extent of separation between the constructs; and the convergent validity verifies the homogeneity of the indicators and their constructs. However, convergent validity can be stated as all its variables are associated to significant and high loadings at least at be significant at $95 \%$. Therefore, it can be stated that scales have convergent validity (Anderson \& Gerbing, 1988).Thus, evidence of convergent validity was provided by the fact that all measurement items loaded on the appropriate constructs. Discriminant validity means that each factor represents a separate dimension (Fornell \& Larcker, 1981). According to Anderson and Gerbing (1988), discriminant validity is the degree of correlation among the constructs, and the correlation between different constructs. It refers to the principle that the indicators for different constructs should not be so highly correlated as to indicate they are measuring the same thing. As mentioned above, correlations were run between the items of several constructs used in this study (Table 3 ). However, in all instances the item correlations satisfied the $\mathrm{R}=$ 0:85 cut-off often used by researchers for this assessment (Garson, 2001), thus suggesting the model demonstrated good discriminant validity. Furthermore, nomological validity refer to the ability of a scale to behave as expected with respect to some other constructs to which it is related (Churchill, 1995). As mentioned above, ethical sales behavior can improve customer trust, customer commitment and customer loyalty. Therefore nomological validity would be demonstrated if the scale were positively and significantly correlated with customer trust, customer commitment and customer loyalty. As stated in Table 3, all correlation coefficients between the dimensions of ethical sales behavior, customer trust, customer commitment and customer loyalty are positive and significant (at $\mathrm{p}<0.01$ ). Thus nomological validity of the scale is demonstrated. Considering the reliability, nomological, convergent, and discriminant validity tests collectively, it's conclude that the measurement model satisfies all the psychometric property requirements. Table 3 shows the means, standard deviations, and intercorrelations for the constructs operationalized in this study.

\section{Hypotheses tests}

A structural equation modeling was conducted to test the hypotheses in order to assess the effect and the significance level of each path in the model. The model shown in Figure 1 was examined and tested using AMOS7. Tests of the hypotheses were performed using a structural equations modeling (SEM). Model fit determines the degree to which the structural equation model fits the sample data. The model was tested and provided good indicators of fit: Chi square / $\mathrm{d} \mathrm{f}=2.834$, (it should be between 0 and 3 with lower values indicating a better fit).with the comparative fit index (CFI) was 0.881 , Tucker-Lewis coefficient (TLI) was 0.868 , ( RFI) was 0.810 (a value of 1.0 indicates perfect fit) and the root mean square error of approximation (RMSEA) was 0.092, indicating a good fit between the theoretical model and the data (Bagozzi \& Yi, 1988; Bearden et al. 1982; Marcoulides \& Schumacker, 1996). The analysis then proceeded to examine the causal relationships between these variables. The results were as expected and provided support for all hypotheses, except H6. The results of the structural model showed that ethical behavior had no significant direct effect on customer loyalty to the bank. Properties of the causal paths, including standardized path coefficients of the research model was shown in Table 5.

\section{Insert Table 5 here}

Figure 2 illustrates path analysis of the structural model. Standardized path coefficients are provided; numbers on the construct indicate total variance explained (R2). Standardized structural path coefficients and $R 2$ values are presented in Figure 2.

\section{Insert Figure 2 here}

In this model the path from ethical sales behavior to customer trust, customer commitment and customer loyalty was calculated, and the standardized coefficient that obtained from ethical behavior to trust and commitment to the bank was positive and highly significant (Standardized coefficient $=.663 ; \mathrm{p}<.01$ And $12 ; \mathrm{p}<.05$ ). Thus, there is support for $\mathrm{H} 1$ and $\mathrm{H} 2$. However, the standardized coefficient that obtained from trust and commitment to customer loyalty was positive and highly significant (Standardized coefficient $=.580$ and $.288 ; \mathrm{p}<.01$ ). 
Therefore, there is support for $\mathrm{H} 4$ and H5. As predicted by H3, the standardized coefficient that obtained from customer trust to customer commitment was also positive and highly significant (Standardized coefficient $=.812$; $\mathrm{p}<.01)$. Thus, there is support for H3. Unfortunately, the standardized coefficient from ethical behavior to customer loyalty was negative but non-significant $(-.134 ; \mathrm{p}>.05)$. Therefore, H6 not supported. That is to say, when trust and commitment was not considered, ethical behavior had a strong and direct effect on customer loyalty to the bank, otherwise if trust and commitment was included in the model, ethical behavior did increase customer loyalty to the bank; yet this effect was not direct, but mediated by trust and commitment. The effects of ethical sales behavior on customer loyalty, therefore flow only through customer trust in and customer commitment to the bank and highly significant (indirect standardized coefficient $=.574 ; \mathrm{p}<.01$ ). Therefore $\mathrm{H7}$ supported. The results concerning the testing of hypotheses are summarized in Table 6.

\section{Insert Table 6 here}

As depicted in figure 2, coefficient of determination (R2) values show that, ethical sales behavior account for $44 \%$ of variance in customer trust; ethical sales behavior and customer trust, account for $80 \%$ of variance in customer commitment; ethical sales behavior, customer trust and customer commitment account for $58 \%$ of variance in customer loyalty. The results are depicted in Figure 2, which show a structural equation modeling. These results suggest that the model is a reasonable basis upon which to test the research hypotheses.

\section{Discussion and implications}

\subsection{Discussion}

The study provides a model that explains how banker's ethical sales behavior is able to generate higher customer loyalty. Therefore, the paper contributed to the ethical sales behavior - customer loyalty relationship literature by empirically validating the role of ethical sales behavior as perceived by the bank customer in developing customer loyalty through customer trust in and customer commitment to the bank. Consistent with previous study, ethical sales behavior was significant predictor of customer trust, customer commitment, and customer loyalty. Moreover, consistent with Chen and Mau (2009); Hansen and Riggle (2009); Roma`n and Ruiz's (2005) and Roma 'n's (2003) study the ethical sales behavior positively affects customer trust. This means that when the ethical sales behavior is perceived to be high, the customer will have more trust in the bank. Likewise, different exploratory studies have shown that customer trust in the salesperson can be earned by the honest actions of sales representatives (Beatty et al. 1996), as well as low-pressure selling techniques (Strutton et al. 1996; Kennedy et al. 2001). According to Chen and Mau (2009), "if the customers think their salesperson's sales behaviors are ethical then they would tend to trust the salesperson as well as the company." The results also show that ethical sales behavior indeed plays a major role in affecting customer trust in and customer commitment to the bank as it has positive effects on customer trust and positive effects on customer commitment. However, the effect on customer trust is stronger than its effect on customer commitment. This result however is inconsistent with the finding of Hansen and Riggle (2009) study. They indicate that the relationship between ethical sales behavior and customer commitment to the salesperson is completely mediated by customer trust in the salesperson. They found that the effects of ethical sales behavior on buyer commitment to the salesperson flow only through buyer trust in the salesperson. Moreover, consistent with Hansen and Riggle (2009), Anderson and Narus (1990), Ganesan (1994), Garbarino and Johnson (1999), finding of this study indicate that, customer trust in the bank has positive effects on customer commitment to the bank. Finally, research analyses indicate that, both of customer trust and customer commitment make positive contributions to customer loyalty. Indeed, the effect of customer trust on customer loyalty is stronger than the effect of customer commitment. These results are in line with Chen and Mau (2009) and Reichheld and Schefter's (2000, p. 107) observation that 'to gain the loyalty of customers, you must first gain their trust'. Once there is customer trust, customer loyalty comes naturally. Customers who perceive the sales behavior to be ethical are more likely to trust the bank and therefore, hold commitment toward the bank. Consequently, customer who trust in the bank and hold commitment to the bank are in turn more likely to exhibit desirable behaviors i.e. more loyal. The finding of this study positions customer trust and customer commitment as the primary mechanism through which the beneficial effects of ethical sales behavior are realized, and supports those who have previously noted the critical role ethical sales behavior plays in facilitating a sense of trust and commitment on the part of the bank customer.

The study implies that banks must emphasize the importance of ethical behavior of individual bankers, and encourage behaviors that will increase customers' confidence in the bank. These findings are in line with the finding of Vegholm and Silver (2008) and Llewellyn (2005), who argues that it is important for financial institutions to set guidelines for individual bankers on how to act fairly, and to develop appropriate training and 
reward mechanisms. The finding is also consistent with those of Seal (1998), who argues that a trustworthy organization starts by building confidence into its internal processes, through training and educating its own employees. Therefore, as argued by Llewellyn (2005) treating customers fairly is a major corporate issue about the responsibility of individual employee. Building upon Llewellyn's (2005) proposed model, the present study has shown that it is indeed in the best interest of financial institutions to strive for corporate fairness. Although this study finding partially replicates previous research (e.g., Hansen \& Riggle, 2009; Chen \& Mau, 2009; Roma'n, 2003; Vegholm \& Silver, 2008; Roma'n \& Munuera, 2005; Llewellyn, 2005; Lagace et al., 1991; Román \& Ruiz 2005), but the other one represent new contributions to the research body. However, it is an attempt to occupy the gab in interrelationships that were uncovered between ethical sales behavior, relationship quality (customer trust and customer commitment) and customer loyalty. The study indicate that the effects of ethical sales behavior on customer loyalty is completely mediated by relationship quality i.e. customer trust and customer commitment.

\subsection{Managerial implications}

This research represents an important step in testing and understanding the dynamics of the relationship between ethical sales behavior and customer loyalty in banking industry. As such it contributes to the limited research exploring the mediating effect of customer trust and customer commitment in this relationship. Results show that perceived ethical behavior has a major impact on the development and maintenance of the customer-bank relationship. Results also reveal that customer trust and customer commitment are an important mediating determinants between the ethical sales behavior and customer loyalty in the bank industry. The managerial implications of study results are quite clear. Thus banks that value the critical importance of long term relationships with their customers, should achieve an environment where the potential for unethical behavior is at a minimum. From a managerial perspective, the ethical sales behavior is a vital determinant of customer trust and customer commitment, which in turn influences customer loyalty in the bank services. Therefore, for those banks wishing to establish a long-term relationship with their customers, how to encourage their employees to uphold ethics when making sales to customers is very important. Bank managers should emphasize that, unethical behavior in any way is not acceptable so long bank attempt to convey trust to their customers so as to build successful relationship with their customer. Studies indicate that an organization's ethical climate influences the ethics of its employees (Verbeke et al., 1996; Wimbush and Shepard 1994). Therefore, creating, implementing, monitoring, and enforcing new codes of ethics represents a positive first step in encouraging ethical salesperson behavior (e.g. Valentine and Barnett (2007) Roma'n \& Munuera, 2005; Verbeke et al., 1996; Wimbush and Shepard 1994). Furthermore, the empirical results of this study strongly support the implementation of previous studies findings and suggestions which indicates that an organization's ethical climate influences the ethics of its employees. In addition to the results of Valentine (2009), study which imply that, ethics training, operating through ethical context can enhance perceptions that the organization has ethical standards. An emphasis on ethical behavior is therefore much more important than selling activities. It's critical for the survival of an organization in a highly competitive market. In other words, salespeople should be managed from an ethical standpoint so that positive long-term customer relationship can be established, and repeat purchases are encouraged from a loyal and established customer base.

\section{References}

Adamson, I., Chan, K-M., and Handford, D. (2003). Relationship marketing: customer commitment and trust as a strategy for the smaller Hong Kong corporate banking sector. International Journal of Bank Marketing, Vol. 21, No. 6/7, pp. 347-58. http://dx.doi.org/10.1108/02652320310498492

Alrubaiee, L., \& Alkaa,ida, F. (2011). The mediating effect of Patient satisfaction in the Patients' perceptions of healthcare quality - Patient trust relationship. International Journal of Marketing Studies, Vol. 3, No. 1; February, 103-127.

Alrubaiee, L., \& Al-Nazer, N. (2010). Investigate the Impact of Relationship Marketing Orientation on Customer Loyalty: The Customer's Perspective. International Journal of Marketing Studies, Vol. 2, No. 1; May, 155-174.

Amyx, D., Bhuian, S., J., Sharma, D., Loveland, E. (2008). Salesperson corporate Ethical values (SCEV) scale: Development and Assessment among salespeople. Journal of Personal Selling \& Sales Management, vol. XXVIII, no. 4 (fall), pp. 387-401.

Anderson, J. C., \& Narus, J. A. (1990). A model of distributor firm and manufacturer firm working partnerships. Journal of Marketing, 54, 42-58. http://dx.doi.org/10.2307/1252172 
Anderson, J.C., and Gerbing, D.W. (1988). Structural equation modeling in practice: a review and recommended two-step approach. Psychological Bulletin, Vol. 103, pp. 411-23. http://dx.doi.org/10.1037/0033-2909.103.3.411

Anderson, J.C., and Narus, J.A. (1998). Business Marketing: Understand What Customers Value. Harvard Business Review, 76 (6), 53-65.

Arnett, Dennis B., \& Badrinarayanan, Vishag. (2005). Enhancing Customer - needs - driven CRM strategies: core selling teams, knowledge management competence, and relationship marketing competence. Journal of Personal Selling \& Sales Management, 25(4), 329-343.

Bagozzi, R. P., and Youjae, Y. (1988). On the evaluation of structural equation models. Journal of the Academy of Marketing Science, 16, (1), 74 - 94. http://dx.doi.org/10.1007/BF02723327

Bearden, W.O., Sharma, S., and Teel, J.E. (1982). Sample size effects on chi-square and other statistics used in evaluating causal models. Journal of Marketing Research, Vol. 19, pp. 425-30. http://dx.doi.org/10.2307/3151716

Beatty, S.E., Mayer, M., Coleman, J.E., Reynolds, K.E., and Lee (1996). Customer-Sales Associate Retail Relationships. Journal of Retailing, 72, 3, pp.223-247. http://dx.doi.org/10.1016/S0022-4359(96)90028-7

Berry, L. L. (1995). Relationship marketing of services - growing interest, emerging perspective. Journal of the Academy of Marketing Science, 23(4), 236-245. http://dx.doi.org/10.1177/009207039502300402

Berry, L.L. (1983). Relationship marketing. In L.L. Berry, G.L. Shostack,\&G.D. Upah (Eds.), Emerging perspectives on services marketing (pp. 25-28). Chicago: American Marketing Association.

Bitner, Mary Jo. (1990). Evaluating Service Encounters: The Effects of Physical Surroundings and Employee Responses. Journal of Marketing, 54, (2) (April) 69-82. http://dx.doi.org/10.2307/1251871

Bonnin,G., Segard,O., and Vialle, P. (2005). Relationship marketing and Innovation: The case of the Launch of Wireless local loop telecommunication services in France. Journal of Services Research, Special Issue (December), 149-171.

Burnett, .M., Pettijohn, C., and Keith, N. (2008). A Comparison of the Ethical Perceptions prospective personal selling and advertising employees. The Marketing Management Journal, 18, 1, 77- 83.

Cater, B., \& Zabkar, V. (2008). Antecedents and consequences of commitment in marketing research services: The client's Perspective. Industrial Marketing Management. http://dx.doi.org/10.1016/j.indmarman.2007.10.004

Charles H. Schwepker, Jr., \& David J. Good (2007b). Sales Management's Influence on Employment and Training in Developing an Ethical Sales Force. Journal of Personal Selling \& Sales Management, 27, 4 (Fall), $327-341$.

Chen, Mei-Fang and Mau, Liang-Hung (2009). The impacts of ethical sales behaviour on customer loyalty in the life insurance industry. The Service Industries Journal, Vol. 29, No. 1, January, 59-74. http://dx.doi.org/10.1080/02642060802116339

Churchill, G. A. Jr. (1995). Marketing Research Methodological Foundations (6th Ed.). Dryden Press, Fort Worth, TX.

Cooper, R.W., \& Frank, G.L. (2002). Ethical challenges in the two main segments of the insurance industry: Key considerations in the evolving financial services marketplace. Journal of Business Ethics, 36(1/2), 5-20. http://dx.doi.org/10.1023/A:1014235908833

Coote, L. V., Forrest, E. J., \& Tam, T.W. (2003). An investigation into commitment in non- Western industrial marketing relationships. Industrial Marketing Management, 32, 595-604. http://dx.doi.org/10.1016/S0019-8501(03)00017-8

Crosby, L.A., Evans, K.R., \& Cowles, D. (1990). Relationship quality in services selling: An interpersonal influence perspective. Journal of Marketing, 54(3), 68-81. http://dx.doi.org/10.2307/1251817

Dawson, Leslie M. (1997). Ethical Differences between Men and Women in the Sales Profession. Journal of Business Ethics, Vol. 16, pp. 1143-1152. http://dx.doi.org/10.1023/A:1005721916646

De Wulf, K., Gaby Odekerken-Schröder and Iacobucci, D. (2001). Investments in Consumer Relationships: A Cross-Country and Cross-Industry Exploration. Journal of Marketing, 65, (4) (October), 33-50. http://dx.doi.org/10.1509/jmkg.65.4.33.18386

Dibb, S., and Meadows, M. (2001). The Application of a Relationship Marketing Perspective in Retail Banking. The Services Industries Journal, 21, 1, pp.169-194. http://dx.doi.org/10.1080/714005011 
Dick, A.S., and Basu, K. (1994). Customer loyalty: Toward an integrated conceptual framework. Journal of the Academy of Marketing Science, 22(2), 99-113. http://dx.doi.org/10.1177/0092070394222001

Doney, P.M., \& Cannon, J.P. (1997). An examination of the nature of trust in buyer-seller relationships. Journal of Marketing, 61(2), 35-51. http://dx.doi.org/10.2307/1251829

Dorsch, M. J., Swanson, S.R., and Kelley, S.W. (1998). The role of relationship quality in the stratification of vendors as perceived by customers. Journal of Academy Marketing Science, Vol 26 (Spring), 128 - 142. http://dx.doi.org/10.1177/0092070398262004

Dubinsky, Alan J., and Michael Levy. (1985). Ethics in Retailing: Perceptions of Retail Salespeople. Journal of the Academy of Marketing Science, Vol. 13 (No. 1), pp. 1-16. http://dx.doi.org/10.1007/BF02729702

Dubinsky, Alan J., Marvin A. Jolson, Ronald E. Michaels, Masaaki Kotabe and Chae Un Lim. (1992). Ethical Perceptions of Field Sales Personnel: An Empirical Assessment. Journal of Personal Selling and Sales Management, Vol. XII (Fall), pp. 9-21.

Dunfee, T.W., and Gunther, R. (1999). Ethical Issues in Financial Services. Business and Society Review, 104, pp.5-10. http://dx.doi.org/10.1111/0045-3609.00032

Dunfee, Thomas W., N. Craig Smith, and William T. Ross. (1999). Social contracts and marketing ethics. Journal of Marketing, 63 (3), 14-32. http://dx.doi.org/10.2307/1251773

Dwyer, F.R., Schurr, P.H., and Oh, S. (1987). Developing buyer - seller relationship. Journal of Marketing, Vol. 51, pp. 11-27. http://dx.doi.org/10.2307/1251126

Eisingerich, Andreas B., and Bell, Simon J. (2007). Maintaining customer relationships in high credence services. Journal of Services Marketing, 21 (4), 253-262. http://dx.doi.org/10.1108/08876040710758559

Ferna'ndez-Laviada, A. (2007). Internal audit function role in operational risk management. Journal of Financial Regulation and Compliance, Vol. 15, No. 2, pp. 143-55. http://dx.doi.org/10.1108/13581980710744039

Ferrell, Mark W. Johnston, and Linda Ferrell. (2007). A framework for personal selling and sales management ethical decision making. Journal of Personal Selling \& Sales Management, vol. XXVII, 4 (fall), pp. 291-299.

Fornell, C., and Larcker, D. (1981). Evaluating Structural Equation Models with Unobservable Variables and Measurement Error. Journal of Marketing Research, 18 (February), 39-50. http://dx.doi.org/10.2307/3151312

Fornell, Claes. (1992). A National Customer Satisfaction Barometer: The Swedish Experience. Journal of Marketing, 56, (1) (Jan.), 6-21. http://dx.doi.org/10.2307/1252129

Futrell, C.M. (2002). Fundamentals of selling: Customers for life (7th ed.). New York: McGraw-Hill.

Ganesan, S. (1994, April). Determinants of long-term orientation in buyer-seller relationships. Journal of Marketing, 58, 1-19. http://dx.doi.org/10.2307/1252265

Garbarino, E., \& Johnson, M. (1999). The different roles of satisfaction, trust and commitment in customer relationships. Journal of Marketing, 63(2), 70-87. http://dx.doi.org/10.2307/1251946

Goff, B.G., Boles, J.S., Bellenger, D.N., and Stojack, C. (1997). The Influence of Salesperson Selling Behaviors on Customer Satisfaction with Products. Journal of Retailing, 73, 2, pp.171-183. http://dx.doi.org/10.1016/S0022-4359(97)90002-6

Gruen, T.W., Summers, J.O., and Acito, F. (2000). Relationship marketing activities, commitment, an membership behaviors in professional associations. Journal of Marketing, 64 (3) (July), 34-49. http://dx.doi.org/10.1509/jmkg.64.3.34.18030

Grunbichler, A., and Darlap, P. (2003). Integration of EU financial markets supervision: harmonization or unification? Journal of Financial Regulation and Compliance, Vol. 12, No. 1, pp. 36-44. http://dx.doi.org/10.1108/13581980410810669

Hair, J.F. Jr, Anderson, R.E., Tatham, R.L., and Black, W.C. (1998). Multivariate Data Analysis (5 ${ }^{\text {th }}$ ed.). Prentice-Hall International, Englewood Cliffs, NJ.

Hall, M.A. (2005). The importance of trust for ethics, law and public policy. Cambridge Quarterly of Healthcare Ethics, Vol. 14, No. 2, pp. 156-67. http://dx.doi.org/10.1017/S096318010505019X

Hansen, John D., and Riggle, Robert J. (2009). Ethical salesperson behaviour in sales relationships. Journal of Personal Selling \& Sales Management, vol. XXIX, no. 2 (spring), pp. 151-166. 
Hasan, M.R., and Severiens, J.T. (2001). The European Central Bank: the search for credibility. Managerial Finance, Vol. 27, No. 9, pp. 12-20. http://dx.doi.org/10.1108/03074350110767376

Hennig-Thurau, Thorsten and Klee, Alexander (1997). The Impact of Customer Satisfaction and Relationship Quality on Customer Retention: A Critical Reassessment and Model Development. Psychology \& Marketing, Vol. 14(8), 737-764. http://dx.doi.org/10.1002/(SICI)1520-6793(199712)14:8<737::AID-MAR2>3.0.CO;2-F

Holden, R.K. (1990). An exploratory study of trust in buyer-seller relationships. Dissertation, University Microfilms International, Ann Arbor, MI.

Howe, V., Hoffman, K.D., and Hardigree, D.W. (1994). The Relationship between Ethical and Customer-Oriented Service Provider Behaviors. Journal of Business Ethics, 13, July, pp.497-506. http://dx.doi.org/10.1007/BF00881295

Hunt, Shelby D., Dennis B. Arnett and Sreedhar Madhavaram (2005). The Explanatory Foundations of Relationship Marketing Theory. Journal of Business \& Industrial Marketing, forthcoming.

Hunt, Van R. Wood and Lawrence B. Chonko (1989). Corporate Ethical Values and Organizational Commitment in Marketing. Journal of Marketing, 53 (3), 79-90. http://dx.doi.org/10.2307/1251344

Johnson, William C., Norapol Chinuntdej and Art Weinstein (1999). Creating value through customer and supplier relationships. Damien McLoughlin, Conor Horan, Proceedings of The 15th Annual IMP Conference, Dublin.

Kaiser, C. P. (1996). Individual, social, and economic determinants of employee absence: An integrative analysis. The Journal of Business and Economic Studies, 3(2), 1-21.

Karande, Kiran, Ha, Jungbok and Singhapakdi, Anusorn (2008). The role of contextual factors in relationship commitment of buyers to foreign suppliers: A survey of Korean importers. Industrial Marketing Management, 37, 856-862. http://dx.doi.org/10.1016/j.indmarman.2008.01.010

Kennedy, M.S., Ferrell, L.K., and Leclair, D.T. (2001). Consumers' Trust of Salesperson and Manufacturer: An Empirical Study. Journal of Business Research, 51, pp.73-86. http://dx.doi.org/10.1016/S0148-2963(99)00039-9

Kim, K., \& Frazier, G. L. (1997). Measurement of distributor commitment in industrial channels of distribution. Journal of Business Research, 40(2), 139-154. http://dx.doi.org/10.1016/S0148-2963(96)00284-6

Kingshott, R. P. J. (2006). The impact of psychological contracts upon trust and commitment within supplier-buyer relationships: A social exchange view. Industrial Marketing Management, 35(6), 724-739. http://dx.doi.org/10.1016/j.indmarman.2005.06.006

Laczniak, Gene R. (1999). Distributed justice, Catholic social teaching, and the moral responsibility of marketers. Journal of Public Policy and Marketing, 18 (2), 125-29.

Lagace, R.R., Dahlstrom, R., and Gassenheimer, J.B. (1991). The relevance of ethical salesperson behavior on relationship quality: the pharmaceutical industry. Journal of Personal Selling \& Sales Management, Vol. 11, pp. $39-47$.

Lam, R., and Burton, S. (2006). SME banking loyalty (and disloyalty): a qualitative study in Hong Kong. International Journal of Bank Marketing, Vol. 24, No. 1, pp. 37. http://dx.doi.org/10.1108/02652320610642335

Lamb, R.B. (1999). Ethics in Financial Services. Business and Society Review, 104, pp.13-17. http://dx.doi.org/10.1111/0045-3609.00033

Lassar, M., Manolis, C., and Winsor, R.D. (2000). Service quality perspectives and satisfaction in private banking. International Journal of Bank Marketing, Vol. 18, No. 4, pp. 181-99. http://dx.doi.org/10.1108/02652320010349067

Lawrence, Chonko B., Thomas R. Wotruba and Terry W. Low. (2002). Direct selling ethics at the top: An industry audit and status report. Journal of Personal Selling and Sales Management, 22 (2), 87-95.

Lemon, K.N., White, T.B., and Winer, R.S. (2002). Dynamic customer relationship management: incorporating future considerations into the service retention decision. Journal of Marketing, Vol. 66, pp. 1-14. http://dx.doi.org/10.1509/jmkg.66.1.1.18447

Levesque, T., and McDougall, G.H.G. (1996). Determinants of customer satisfaction in retail banking. International Journal of Bank Marketing, Vol. 14, No. 7, pp. 12-20. http://dx.doi.org/10.1108/02652329610151340 
Liljander, V., and Mattson, J. (2002). Impact of Customer Pre consumption Mood on the Evaluation of Employee Behavior in Service Encounters. Psychology and Marketing, 19, pp.837-860. http://dx.doi.org/10.1002/mar.10040

Yi Liu, Yuan Li, Lei Tao and Ying Wang (2008). Relationship stability, trust and relational risk in marketing channels: Evidence from China. Industrial Marketing Management, 37, 432-446. http://dx.doi.org/10.1016/j.indmarman.2007.04.001

Llewellyn, D.T. (2005). Trust and confidence in financial services: a strategic challenge. Journal of Financial Regulation and Compliance, Vol. 13 No. 4, p. 333. http://dx.doi.org/10.1108/EUM0000000007304

Lund, Daulatram. (2000). An empirical examination of marketing professionals' ethical behavior in differing situations. Journal of Business Ethics, 24, 331-42. http://dx.doi.org/10.1023/A:1006005823045

Madill, J.J., Feeney, L., Riding, A., and Haines, G.H. Jr. (2002). Determinants of SME owners' atisfaction with their banking relationship: a Canadian study. International Journal of Bank Marketing, Vol. 20, No. 2, pp. 86-98. http://dx.doi.org/10.1108/02652320210419698

Mantel, Susan Powell (2005). Choice or perception: How affect influences choices among salespeople. Journal of Personal Selling \& Sales Management, Vol. XXV, No. 1, (Winter 2005), pp. 43-55.

Marcoulides, G.A., \& Schumacker, R.E. (1996). Advanced structural equation modeling. Mahwah, NJ: Erlbaum. Masciandro, D., Nieto, M.J., and Prast, H. (2007). Who pays for banking supervision? Principles and trends. Journal of Financial Regulation and Compliance, Vol. 15, No. 3, pp. 303-26. http://dx.doi.org/10.1108/13581980710762291

Matthew T. Seevers, Steven J. Skinner and Scott W. Kelley (2007). A social network perspective on sales force ethics. Journal of Personal Selling \& Sales Management, Vol. XXVII, No. 4, (Fall 2007), pp. 341-353. http://dx.doi.org/10.2753/PSS0885-3134270405

Mishra, Karen E., and Li, Cong. (2008). Relationship Marketing in Fortune 500 U.S. and Chinese Web Sites. Journal of Relationship Marketing, 7 (1), 29-43. http://dx.doi.org/10.1080/15332660802067882

Morgan, R.M., and Hunt, S.D. (1994). The commitment - trust theory of relationship marketing. Journal of Marketing, Vol. 58(3), pp. 20-38. http://dx.doi.org/10.2307/1252308

Narayandas, D., \& Rangan, V. (2004). Building and sustaining buyer-seller relationships in mature industrial markets. Journal of Marketing, 68(3), 63-77. http://dx.doi.org/10.1509/jmkg.68.3.63.34772

Newell, Frederick (1997). The New Rules of Marketing: How to Use One-to-One Relationship Marketing to be the Leader in your Industry. MC Graw- Hill, New York.

Nill, Alexander and Schibrowsky, John A. (2007). Research on Marketing Ethics: A Systematic Review of the Literature. Journal of Macro marketing, 27, 256-273. http://dx.doi.org/10.1177/0276146707304733

Nunnally, J.C. (1978). Psychometric theory (2nd ed.). New York: McGraw Hill.

Oliver, R.L. (1999). Whence Consumer Loyalty. Journal of Marketing, Vol. 63, No. 4 (special issue), pp. 33-44.

Palmatier, Robert W., Dant, Rajiv P., Grewal, Dhruv \& Evans, Kenneth R. (2006). Factors Influencing the Effectiveness of Relationship Marketing: A Meta-Analysis. Journal of Marketing, 70 (4) (October), 136-53. http://dx.doi.org/10.1509/jmkg.70.4.136

Palmatier, Robert W., Lisa K. Scheer and Jan-Benedict E.M. Steenkamp (2007). Customer Loyalty to Whom? Managing the Benefits and Risks of Salesperson-Owned Loyalty. Journal of Marketing Research, 44 (2), 185-199. http://dx.doi.org/10.1509/jmkr.44.2.185

Pressey, A.D., and Mathews, B.P. (2000). Barriers to relationship marketing in consumer retailing. Journal of Services Marketing, Vol.14, No.1, pp. 37-52.

Prim, I. (2004). Relationship Marketing of Services: An analysis of service quality and service encounters through relations norms. [Online] Available: http://www.dmsp.Dauphine.fr/DMPS/cahiers/CR270.pdf.

Reddy, S.K., and Czepiel, J.A. (1999). Measuring and Modeling the Effects of Long-Term Buyer-Seller Relationships in Corporate Financial Services Markets. Journal of Business Research, 46, pp.235-244. http://dx.doi.org/10.1016/S0148-2963(98)00038-1

Reichheld, Frederick F., and Phil Schefter (2000). E-Loyalty, Your Secret Weapon on the Web. Harvard Business Review, 78 (4), 105-113. 
Reynolds, K.F., and Beatty, S.E. (1999). Customer Benefits and Company Consequences of Customer-Salesperson Relationships in Retailing. Journal of Retailing, 75, 1, pp.11-32. http://dx.doi.org/10.1016/S0022-4359(99)80002-5

Román, Sergio (2003). The Impact of Ethical Sales Behaviour on Customer Satisfaction, Trust and Loyalty to the Company: An Empirical Study in the Financial Services Industry. Journal of Marketing Management, 19 (9-10), 915-939.

Sanzo, M.J., Santos, M.L.,Vazquez, R., and Alvarez, L. (2003). The Role Market Orientation In Business Dynamic Relationships: Testing an Integrator Model. Journal of marketing Management, 19, 73-107. http://dx.doi.org/10.1362/026725703763771971

Schwepker, Charles H. Jr., and David J. Good (2004). Marketing Control and Sales force Customer Orientation. Journal of Personal Selling \& Sales Management, 24 (Summer), 167-79.

Schwepker, Charles H. Jr., and David J. Good (2007a). Exploring Sales Manager Quota Failure FROM AN ETHICAL PERSPECTIVE. The Marketing Management Journal, Volume 17, Issue 2, Pages 156-168.

Schwepker, Charles H., Jr., and David J. Good (2005). Marketing Control and Sales Force Customer Orientation. Journal of Personal Selling \& Sales Management, 23, 3 (Summer), 167-179.

Seal, W.B. (1998). Relational banking and the management of organizational trust. International Journal of Bank Marketing, Vol. 16 No. 3, pp. 102-7. http://dx.doi.org/10.1108/02652329810213457

Selnes, F. (1998). Antecedents and Consequences of Trust and Satisfaction in Buyer-Seller Relationships. European Journal of Marketing, 32, 3/4, pp.305-322. http://dx.doi.org/10.1108/03090569810204580

Sergio Román \& José Luis Munuera (2005). Determinants and Consequences of Ethical Behaviour: An Empirical Study of Salespeople. European Journal of Marketing, 39 (5-6), 473-495. http://dx.doi.org/10.1108/03090560510590674

Sergio Roman and Salvador Ruiz (2005). Relationship Outcomes of Perceived Ethical Sales Behavior: The Customer's Perspective. Journal of Business Research, 58 (4), 439-445. http://dx.doi.org/10.1016/j.jbusres.2003.07.002

Sharma, N., and P.G. Patterson (2000). Switching Costs, Alternative Attractiveness and Experience as Moderators of Relationship Commitment in Professional, Consumer Services. International Journal of Service Industry Management, 11 (November) 470-490. http://dx.doi.org/10.1108/09564230010360182

Sin. Leo Y.M., Tse, Alan C.B., Yau, Oliver H.M., Lee, Jenny S.Y. (2002). The effect of relationship marketing orientation on business performance in a service- oriented economy. Journal of Services Marketing, Vol. 16, No. 7, pp. 656-676.

Sirdeshmukh, D., Singh, J., \& Sabol, B. (2002). Consumer trust, value, and loyalty in relational exchanges. Journal of Marketing, 66(1), 15-37. http://dx.doi.org/10.1509/jmkg.66.1.15.18449

Sparks, John R., and Mark Johlke (1996). Factors Influencing Student Perceptions of Unethical Behavior by Personal Salespeople: An Experimental Investigation. Journal of Business Ethics, Vol. 15, pp. 871-887. http://dx.doi.org/10.1007/BF00381855

Stanko, M., Bonner, J., Calantone, R. (2007). Building commitment in buyer-seller relationships: A tie strength perspective, Industrial Marketing Management, $36 \quad$ (2007), 1094-1103. http://dx.doi.org/10.1016/j.indmarman.2006.10.001

Strout, Erin (2002). To Tell the Truth. Sales and Marketing Management, 154 (July), 40-47.

Strutton, D., Pelton, L. E., and Tanner, J. F. Jr. (1996). Shall We Gather in the Garden: The effect of Ingratiatory Behaviours on Buyer Trust in Salespeople. Industrial Marketing Management, 25, pp.151. http://dx.doi.org/10.1016/0019-8501(95)00074-7

Swan, J.E., Bowers, M.R., and Richardson, L.D. (1999). Customer Trust in the Salesperson: An Integrative Review and Meta-Analysis Of The Empirical Literature. Journal of Business Research, 44, 2, pp.93-10. http://dx.doi.org/10.1016/S0148-2963(97)00244-0

Takala, T., and O. Uusitalo. (1996). An Alternative View of Relationship Marketing: A Framework for Ethical Analysis. European Journal of Marketing, 30(2), 45-60. http://dx.doi.org/10.1108/03090569610106644 
Valentine, Sean (2009). Ethics training, ethical context, and sales and marketing professionals satisfaction with supervisors and coworkers. Journal of Personal Selling \& Sales Management, Vol. XXIX, No. 3 (summer), pp. $227-242$.

Valentine, Sean and Tim Barnett (2007). Perceived Organizational Ethics and the Ethical Decisions of Sales and Marketing Personnel. Journal of Personal Selling \& Sales Management, 27, 4 (Fall), 373-388.

Vegholm, Fatima and Silver, Lars (2008). The impact of corporate fairness on the bank-SME relationship. Journal of Financial Regulation and Compliance, Vol. 16 No. 4, 2008 pp. 352-364. http://dx.doi.org/10.1108/13581980810918413

Veloutsou, C., Saren, M., and Tzokas, N. (2002). Relationship Marketing: What If...? European Journal of Marketing, 36(4), 433-449. http://dx.doi.org/10.1108/03090560210417255

Verbeke, W., Ouwerkerk, C., and Peelen, E. (1996). Exploring the contextual and individual factors on ethical decision making of salespeople. Journal of Business Ethics, Vol. 15, pp. 1175-87. http://dx.doi.org/10.1007/BF00412816

Walter, Achim, Thomas Ritter, and Hans Georg Gemünden (1999). Value-creating Functions of Customer Relationships from a Supplier's Perspective: Theoretical Considerations and Empirical Results, working paper.

Wang, C.L., Siu, N., and Barnes, B. (2008). The significance of trust and renqing in the long-term orientation of Chinese business-to-business relationships. Industrial Marketing Management, 37 (2008), 819-824. http://dx.doi.org/10.1016/j.indmarman.2008.01.008

Weeks, Loe, Chonko, Martinez, and Wakefield (2006). Cognitive moral development and the impact of perceived organizational ethical climate on the search for sales force excellence: A cross-cultural study. Journal of Personal Selling \& Sales Management, vol. XXVI, no. 2 (spring 2006), pp. 205-217.

Weeks, William A., Terry W. Loe, Lawrence B. Chonko, and Kirk Wakefield (2004). The Effect of Perceived Ethical Climate on the Search for Sales Force Excellence. Journal of Personal Selling \& Sales Management, 24, 3 (Summer), 199-214.

Wetzels, M., De Ruyter, K., \& Van Birgelen, M. (1998). Marketing service relationships: The role of commitment. Journal of Business \& Industrial Marketing, 13(4/5), 406-423. http://dx.doi.org/10.1108/08858629810226708

Wilson, D.T. (1995). An integrated model of buyer - seller relationships. Journal of the Academy of Marketing Science, Vol. 23, No. 4, pp. 335-45. http://dx.doi.org/10.1177/009207039502300414

Wimbush, J.C., and J.M. Shepard (1994). Toward Understanding of Ethical Climate: Its Relationship to Ethical Behavior and Supervisory Influence. Journal of Business Ethics, 13 (August), 637-647. http://dx.doi.org/10.1007/BF00871811

Wimbush, James C., Jon M. Shepard, and Steven E. Markham (1997). An Empirical Examination of the Relationship Between Ethical Climate and Ethical Behavior from Multiple Levels of Analysis. Journal of Business Ethics, 16 (16), 1705-1716. http://dx.doi.org/10.1023/A:1017952221572

Wray, B., Palmer, A., \& Bejou, D. (1994). Using neural network analysis to evaluate buyer-seller relationships. European Journal of Marketing, 28(10), 32-48. http://dx.doi.org/10.1108/03090569410075777

Yim, Chi Kin (Bennett), TSE, David K., \& Chan, Kimmy Wa (2008). Strengthening Customer Loyalty Through Intimacy and Passion: Roles of Customer - firm Affection and Customer - Staff Relationships in Services. Journal of Marketing Research, 45 (December), 741- 756. http://dx.doi.org/10.1509/jmkr.45.6.741 
Table 1. Cronbach's alpha coefficient of study variables

\begin{tabular}{|l|l|c|c|}
\hline No. & Dimension & Items Number & Coefficient \\
\hline 1 & Ethical sales behavior & 5 & 0.865 \\
\hline 2 & Customer trust in the sales person & 8 & 0.931 \\
\hline 3 & Customer Commitment & 7 & 0.898 \\
\hline 4 & Customer loyalty & 6 & 0.942 \\
\hline \multicolumn{2}{r|}{ All Dimensions } & 26 & 0.960 \\
\hline
\end{tabular}

Table 2. Construct measurement summary

\begin{tabular}{|c|c|c|}
\hline Statements & Factor loading & $\begin{array}{l}\text { Variance } \\
\text { Explained \% }\end{array}$ \\
\hline Ethical sales behavior ( Cronbach Alpha: 0.865 ) & & 65.284 \\
\hline 1. The Bank salesperson lies about availability in order to make a sale (R). & .784 & \\
\hline 2. The Bank salesperson lies about competition in order to make the sale (R). & .788 & \\
\hline $\begin{array}{l}\text { 3. The Bank salesperson gives answers when he/she does not really know the } \\
\text { answers (R). }\end{array}$ & .841 & \\
\hline $\begin{array}{l}\text { 4. The Bank salesperson applies sales pressure even though he/she knows the } \\
\text { product is not right for me (R). }\end{array}$ & .861 & \\
\hline $\begin{array}{l}\text { 5. The Bank salesperson paints rosy pictures of the products to make them } \\
\text { sound as good as possible }(\mathrm{R}) \text {. }\end{array}$ & .762 & \\
\hline Customer trust ( Cronbach Alpha:0.931) & & 67.408 \\
\hline 6. I believe that the Bank has my interest in mind. & .806 & \\
\hline 7. I feel that the Bank is trustworthy. & .819 & \\
\hline 8. I have confidence of the products and services of this Bank. & .819 & \\
\hline $\begin{array}{l}\text { 9. Generally speaking, you do not have to worry at all in dealing with this } \\
\text { Bank. }\end{array}$ & .778 & \\
\hline 10. The Bank can be relied on to keep their promises. & .857 & \\
\hline 11. T11. I believe the information that the Bank provides. & .839 & \\
\hline 12. This Bank is honest and truthful. & .873 & \\
\hline 13. This Bank can be counted on to do what is right. & .772 & \\
\hline Customer Commitment ( Cronbach Alpha: 0.898 ) & & 62.216 \\
\hline $\begin{array}{l}\text { 14. I want to remain a customer of this Bank because I genuinely enjoy my } \\
\text { relationship with. }\end{array}$ & .730 & \\
\hline 15. I have a strong sense of loyalty towards this Bank. & .807 & \\
\hline 16. My relationship with this Bank is one that I really care about. & .801 & \\
\hline 17. I feel a strong sense of belonging to this Bank. & .780 & \\
\hline 18. I am very committed to the relationship with this Bank. & .788 & \\
\hline 19. My relationship with this Bank is very important to me. & .807 & \\
\hline $\begin{array}{l}\text { 20. My relationship with this Bank is something I intend to maintain } \\
\text { Indefinitely. }\end{array}$ & .806 & \\
\hline Customer loyalty( Cronbach Alpha: 0.942 ) & & 77.734 \\
\hline 21. I am willing to place my future business with this Bank. & .882 & \\
\hline $\begin{array}{l}\text { 22. This Bank is my first choice when I want to re buy or re patronize a } \\
\text { preferred product or service in the future. }\end{array}$ & .820 & \\
\hline 23. I will recommend the Bank to my friends and relatives. & .915 & \\
\hline 24. I will introduce the Bank with positive evaluation. & .916 & \\
\hline 25. I feel satisfied with placing a contract with this Bank. & .885 & \\
\hline 26. I am willing to encourage others to do business with this Bank. & .867 & \\
\hline
\end{tabular}

Note: $\mathrm{R}$ denotes items requiring reverse scoring 
Table 3. Correlation matrix and descriptive statistics of study variables $(n=217)$

\begin{tabular}{|l|c|c|c|c|}
\hline & $\begin{array}{c}\text { Ethical sales } \\
\text { behavior }\end{array}$ & Trust & Commitment & Loyalty \\
\hline Ethical sales behavior & 1 & & & \\
\hline Trust & $.663(* *)$ & 1 & & \\
\hline Commitment & $659(* *)$ & $.891(* *)$ & 1 & \\
\hline Loyalty & $.440(* *)$ & $.748(* *)$ & $\left..716^{* *}\right)$ & 1 \\
\hline Mean & 5.2009 & 4.8992 & 5.000 & 4.472 \\
\hline Std. deviation & 1.051 & 1.034 & 0.949 & 1.337 \\
\hline
\end{tabular}

Note: $* *$ Correlation is significant at the 0.01 level (2-tailed).

Table 4. Confirmatory factor analysis: measurement property

\begin{tabular}{|l|l|l|c|c|c|c|c|}
\hline & & & Estimate & S.E. & C.R. & P & Label \\
\hline E5 & $<---$ & Ethical Behavior & .707 & & & & \\
\hline E4 & $<---$ & Ethical Behavior & .833 & .114 & 11.158 & $* * *$ & par_1 \\
\hline E3 & $<---$ & Ethical Behavior & .811 & .115 & 10.906 & $* * *$ & par_2 \\
\hline E2 & $<---$ & Ethical Behavior & .711 & .119 & 9.658 & $* * *$ & par_3 \\
\hline E1 & $<---$ & Ethical Behavior & .699 & .124 & 9.504 & $* * *$ & par_4 \\
\hline T1 & $<---$ & Trust & .778 & & & & \\
\hline T2 & $<---$ & Trust & .771 & .076 & 12.324 & $* * *$ & par_5 \\
\hline T3 & $<---$ & Trust & .776 & .077 & 12.416 & $* * *$ & par_6 \\
\hline T4 & $<---$ & Trust & .725 & .078 & 11.427 & $* * *$ & par_7 \\
\hline T5 & $<---$ & Trust & .842 & .079 & 13.768 & $* * *$ & par_8 \\
\hline T6 & $<---$ & Trust & .828 & .076 & 13.475 & $* * *$ & par_9 \\
\hline T7 & $<---$ & Trust & .866 & .083 & 14.299 & $* * *$ & par_10 \\
\hline T8 & $<---$ & Trust & .748 & .078 & 11.872 & $* * *$ & par_11 \\
\hline C7 & $<---$ & commitment & .779 & & & & \\
\hline C6 & $<---$ & commitment & .788 & .084 & 12.444 & $* * *$ & par_12 \\
\hline C5 & $<---$ & commitment & .712 & .088 & 11.006 & $* * *$ & par_13 \\
\hline C4 & $<---$ & commitment & .691 & .084 & 10.623 & $* * *$ & par_14 \\
\hline C3 & $<---$ & commitment & .760 & .082 & 11.912 & $* * *$ & par_15 \\
\hline C2 & $<---$ & commitment & .793 & .082 & 12.553 & $* * *$ & par_16 \\
\hline C1 & $<---$ & commitment & .692 & .091 & 10.645 & $* * *$ & par_17 \\
\hline L6 & $<---$ & Loyalty & .844 & & & & \\
\hline L5 & $<---$ & Loyalty & .861 & .063 & 16.391 & $* * *$ & par_18 \\
\hline L4 & $<---$ & Loyalty & .906 & .059 & 17.944 & $* * *$ & par_19 \\
\hline L3 & $<---$ & Loyalty & .899 & .058 & 17.721 & $* * *$ & par_20 \\
\hline L2 & $<---$ & Loyalty & .770 & .061 & 13.647 & $* * *$ & par_21 \\
\hline L1 & $<---$ & Loyalty & .856 & .065 & 16.218 & $* * *$ & par_22 \\
\hline
\end{tabular}

Note: Standardized Regression Weights: (Group number 1 - Default model) 
Table 5. Result of structural equation modeling: standardized direct, indirect and overall effects

\begin{tabular}{|c|c|c|c|c|}
\hline & To & \multirow{2}{*}{$\begin{array}{c}\text { Customer } \\
\text { trust }\end{array}$} & \multirow{2}{*}{$\begin{array}{c}\text { Customer } \\
\text { Commitment }\end{array}$} & \multirow{2}{*}{$\begin{array}{c}\text { Customer } \\
\text { Loyalty }\end{array}$} \\
\hline & From & & & \\
\hline \multirow{3}{*}{ Direct Effect } & Ethical sales behavior & .663 & .120 & -.134 \\
\hline & Customer trust & .000 & .812 & .580 \\
\hline & Customer Commitment & .000 & .000 & 288 \\
\hline \multirow{3}{*}{ Indirect Effect } & Ethical sales behavior & .000 & .539 & .574 \\
\hline & Customer trust & .000 & .000 & .234 \\
\hline & Customer Commitment & .000 & .000 & .000 \\
\hline \multirow{3}{*}{ Total Effect } & Ethical sales behavior & .663 & .659 & .440 \\
\hline & Customer trust & .000 & .812 & .814 \\
\hline & Customer Commitment & .000 & .000 & .288 \\
\hline
\end{tabular}

Table 6. Hypotheses testing results of the structural equation model

\begin{tabular}{|c|l|c|c|}
\hline Hypothesis & \multicolumn{1}{|c|}{ Causal path } & $\begin{array}{c}\text { Standardized } \\
\text { Coefficients }\end{array}$ & Test result \\
\hline H1 & Ethical sales behavior $\rightarrow$ customer trust & $0.663^{* *}$ & supported \\
\hline H2 & $:$ Ethical sales behavior $\rightarrow$ customer commitment & $0.120^{*}$ & supported \\
\hline H3 & customer trust $\rightarrow$ customer commitment & $0.812^{* *}$ & supported \\
\hline H4 & customer trust $\rightarrow \quad$ customer Loyalty & $0.580^{* *}$ & supported \\
\hline H5 & $:$ customer commitment $\rightarrow$ customer Loyalty & $0.288^{* *}$ & supported \\
\hline H6 & Ethical sales behavior $\rightarrow$ customer Loyalty & -0.134 & not supported \\
\hline H7 & $\begin{array}{l}\text { Ethical sales behavior } \rightarrow \text { customer Loyalty } \\
\text { Indirect effect through customer trust and customer } \\
\text { Commitment as mediators }\end{array}$ & $0.574^{* *}$ & supported \\
\hline
\end{tabular}

Note: $* *$ indicates $\mathrm{p}<0.01: *$ indicates $\mathrm{p}<0.05$.

H 6

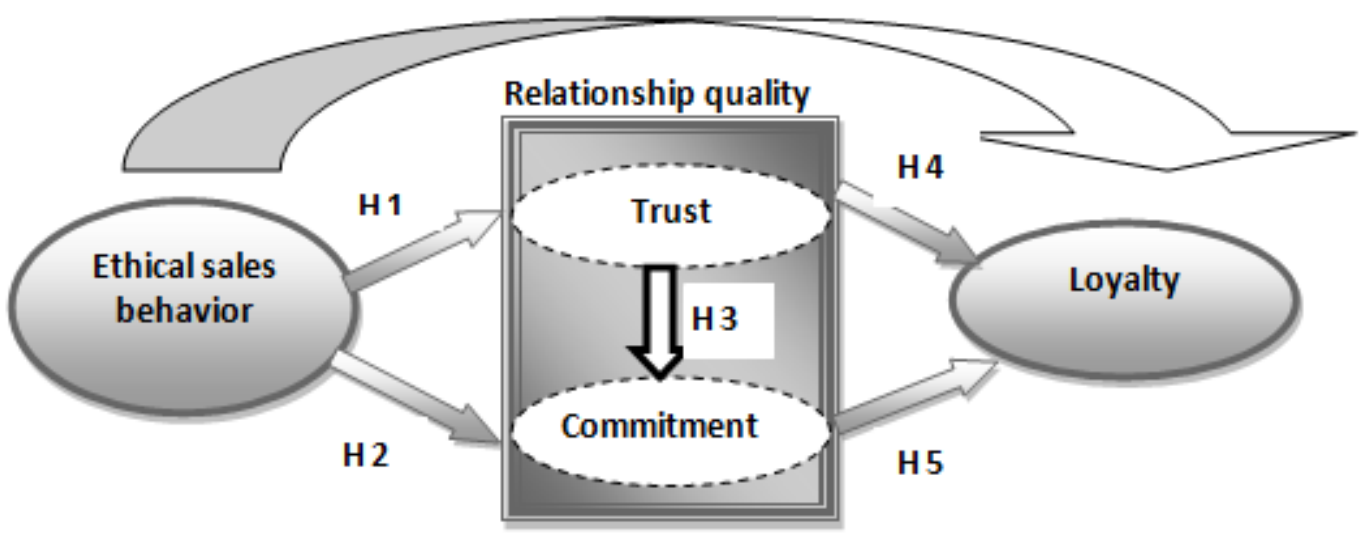

Figure 1. The conceptual model 


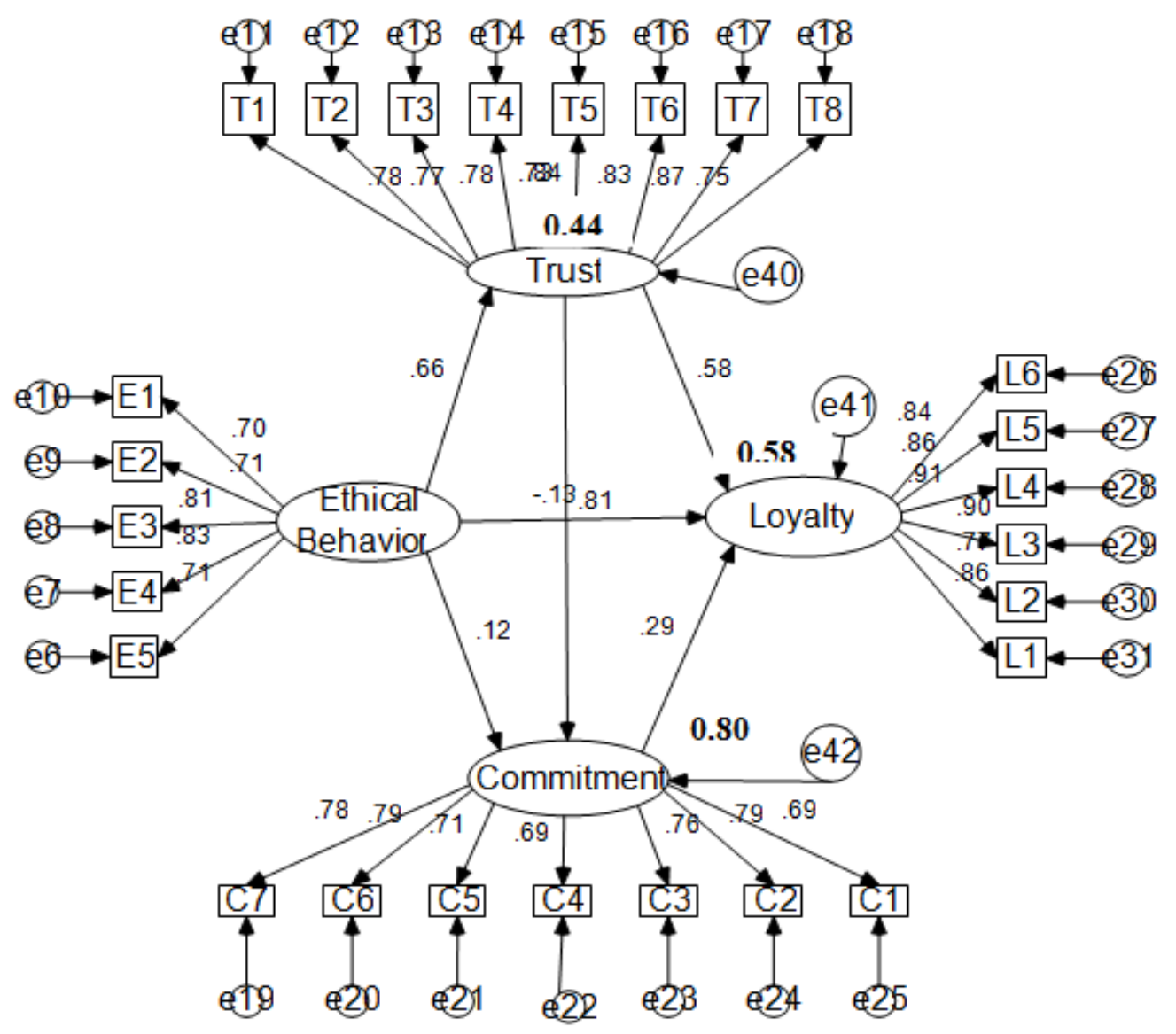

Figure 2. Result of structural equation modeling 